\title{
Visualization of mining and geological data based on coal mine KWK "Knurów-Szczygłowice” Ruch "Knurów”
}

\author{
Marta Sobstyl, Mateusz Jabłoński \\ AGH University of Science and Technology, Faculty of Mining Surveying and Environmental Engineering; al. Mickiewicza 30, \\ 30-059 Krakow, Poland; e-mail: marta.sobstyl@gmail.com \\ (C) 2015 Authors. This is an open access publication, which can be used, distributed and reproduced in any medium according \\ to the Creative Commons CC-BY 4.0 License requiring that the original work has been properly cited.
}

The aim of this work was to create a 3D model of underground workings of fragment coal mine KWK "Knurów-Szczygłowice" Ruch "Knurów" for $550 \mathrm{~m}$ and $650 \mathrm{~m}$ level. The 3D model has been developed on basis of the digital, two-dimensional mining map (Maciaszek et al. 2010). Initially, completeness of mining maps has been checked, which allows one to select the south - east area to create the model. The elements were created in 3D space such as: boundaries of the mining area, protective pillars, workings wall, boreholes (Drąg 2011). Creating a model one started from the construction of the simplest form, the axis model. In turn moving to more complex visualization a circular cross-section model has been created. For workings walls the basis for showing them in three-dimensional space was to extrude the surface along the $\mathrm{Z}$ axis equal to the thickness of the deposit (Galica 2011). More complex task was modeling protective pillars because of their shape of the area. An important element was to define transparency level each of element from the model. Modeling was performed in Microstation, AutoCAD and with GeoLisp system, which bases on AutoCAD. Afterwards, conclusions for creating three-dimensional mining maps and using programs have been performed (Poniewiera 2008, Krawczyk 2008). The result of the work is an animation showing selected elements of mining map in 3D space (Mertas \& Poniewiera 2009).

\section{REFERENCES}

Drąg D., 2011. Próba zdefiniowania trójwymiarowych symboli map górniczych wraz z koncepcja przestrzennej prezentacji wyrobisk górniczych. AGH WGGiIŚ, Kraków [MSc thesis].

Galica D., 2011. Kartograficzna wizualizacja trójwymiarowych modeli podziemnych wyrobisk górniczych. [in:] Dyczko A. \& Krawczyk A. (red.), Geomatyka górnicza praktyczne zastosowania, Wydawnictwo Fundacji dla AGH, Kraków, 203-215.

Krawczyk A., 2008. Zastosowanie Microstation do wizualizacji i animacji 3D w górnictwie. Ochrona środowiska na terenach górniczych: VII konferencja naukowo-techniczna: Szczyrk 2-4 czerwiec 2008, ZGSIiTG, Katowice, 127-129.

Maciaszek J., Gawałkiewicz R. \& Gawałkiewicz I., 2010. Od modelu do numerycznej mapy przestrzennej. Geologia: kwartalnik Akademii Górniczo-Hutniczej im. Stanisława Staszica w Krakowie, 36, 3, 331-344.

Mertas J. \& Poniewiera M., 2009. Współczesne funkcje kartografii górniczej. X Dni Miernictwa Górniczego i Ochrony Terenów Górniczych: Kraków, 28-29.05.2009, AGH, Kraków.

Poniewiera M., 2008. Generowanie numerycznego modelu złoża w programie Autodesk Civil 3D. Zeszyty Naukowe Politechniki Śląskiej. Seria Górnictwo, Gliwice, 243-252. 